Meta

Journal des traducteurs

Translators' Journal

\title{
Typology of Translation in the Classroom
}

\section{Marieke Van Willigen-Sinemus}

Volume 33, numéro 4, décembre 1988

Symposium AILA 1987, Sydney

URI : https://id.erudit.org/iderudit/004160ar

DOI : https://doi.org/10.7202/004160ar

Aller au sommaire du numéro

Éditeur(s)

Les Presses de l'Université de Montréal

ISSN

0026-0452 (imprimé)

1492-1421 (numérique)

Découvrir la revue

Citer cet article

Van Willigen-Sinemus, M. (1988). Typology of Translation in the Classroom.

Meta, 33(4), 472-479. https://doi.org/10.7202/004160ar d'utilisation que vous pouvez consulter en ligne.

https://apropos.erudit.org/fr/usagers/politique-dutilisation/ 


\title{
TYPOLOGY OF TRANSLATION IN THE CLASSROOM
}

\author{
MARIEKE VAN WILLIGEN-SINEMUS \\ University of Utrecht, Holland
}

\begin{abstract}
When asked to distinguish translation in the classroom from other types of translation, one is tempted to cite the by now well-known comment by HÖNIG and KUSSMAUL :

The students translate a text which they do not understand for an addressee whom they do not know. And the product of their labours is not infrequently assessed by a university lecturer who has neither practical experience as a translator nor theoretical knowledge of translation sciencel.
\end{abstract}

To which one could add in the case of translating into the foreign language : "[the students translate] into a language they have not as yet mastered". In fact there are two kinds of translation in two kinds of classrooms :

a) translations by students participating in courses specifically directed towards learning how to translate who already have a high standard of proficiency in target and source language (in institutes like ESIT in Paris and the "Institut für Uebersetzer- und Dolmetscherausbildung" in Vienna)

b) translations by students as an exercise during second-language acquisition classes. These students usually are not very proficient in the foreign language and sometimes not in their mother tongue either.

In this article we will concern ourselves only with the products of the second type of translation and more specifically with the translations from $\mathrm{L} 1$ into $\mathrm{L} 2$, i.e. from the mother tongue into a foreign language.

We will try to define the lexical and syntactical characteristics of these translations, without paying any attention to possible errors, in order to show that the characteristics of these translations differ considerably from the characteristics of translations (of the same kind of texts) made by professional translators.

Although our research was done on translations made by a relatively small group of Dutch students learning French, we have reason to believe that the research may be valid for other languages as well ${ }^{2}$, and may thus serve to establish a typology of translation in the classroom.

\section{THE RESEARCH}

The students were third-year students in the department of Romance languages at the State University of Utrecht who had never actually translated before, except for the odd isolated sentence during vocabulary, grammar and writing classes. The group consisted of 17 students. On the basis of the marks they had been allotted at the end of the second year for grammar and vocabulary proficiency, they were divided into 3 groups :

(a) students who passed the tests with marks averaging

8 out of 10

(b) students who averaged 7 out of 10
(8 students)

(5 students) 
(c) students who averaged 6 out of 10

(4 students)

Some members of group (c) had failed the tests once or twice previously.

The students were asked to write a composition of 200-250 words in Dutch, their mother tongue, on an assigned argumentative subject. This subject was introduced orally as an anecdote on which they were subsequently invited to comment in writing. In this way it was possible to avoid putting words or even whole sentences into their minds. A few days later they were asked to translate a Dutch text of about the same length on the same subject. This text was both syntactically more complex and lexically more varied (for details of criteria see 2.0 below) than any of the compositions produced by the students (see Appendix 1), although it contained only lexical elements and syntactic structures which the students could be assumed to be able to translate after two years at university (C- text).

A few days later, they were once more asked to translate a Dutch text of approximately the same length and on the same topic. This time, however, the text was lexically much less varied and syntactically simpler (see Appendix 1) than any of the compositions they had written themselves (S-text).

All the translations were made without the use of a dictionary.

\section{THE CRITERIA}

\subsection{THE LEXICAL VARIETY INDEX}

The lexical variety index was expressed by dividing the number of new meaningful words (i.e. words that had not as yet been used in this particular composition with the exception of grammatical words like articles, propositions, etc.) by the total number of words in the composition. It is important to state again that we were not concerned with errors, only with variety. So all words were counted whether they were appropriate or not, and whether they contained errors or not.

\subsection{SYNTACTICAL COMPLEXITY}

Syntactical complexity can be expressed in three ways :

a) average clause length

b) ratio of subordinate clauses to main clauses

c) average $\mathrm{T}$-unit length.

HUNT (1967) states that in mother tongue writing the average length of the T-unit ("one main clause with all subordinate or non-clausal structures attached to it") is an indication of maturity. Advanced students are expected to use fewer, but longer T-units.

As to the subordination index, HUNT states that the tendency to write subordinate clauses in the native language peaks somewhere during the later years of high school and that this index is less accurate for measuring syntactic maturity for older students. But if one considers that foreign language students are in their early stage of acquiring $L 2$, it might still prove useful as a measure.

MELLON (1981) finds the mean clause length to be the most valid measure of syntactic maturity for older students and adults. Although these measures were initially used for mother tongue writing, they have also been used for measuring L2 writing ability. In addition to the subordination index, we counted the number of subordinating connectives (or "linkers").

2.3 Although the indexes for lexical variety and syntactical complexity described in 2.2 are the ones most often used to characterize students' writing, we decided to take into account one further variable : the verb/noun ratio. We had noted that some stu- 
dents used predominantly verbs in their Dutch composition and some predominantly nouns, while others had an even distribution of the two categories. The ability to use a verbal noun instead of a subordinate clause is also a sign of language mastery ("a son arrivée" instead of "quand il est arrivé"). Written language, for example, contains a higher percentage of nouns than oral language.

2.4 In addition to the above we measured the length (in number of words) of source texts and translations.

\section{THE FINDINGS}

We considered the composition and the translations of the C-text and the S-text of each of the three groups separately. In this section we will present the findings concerning the first group (students who all had a high standard of proficiency in grammar and vocabulary). The second group showed very much the same results. The third group (being in fact more heterogeneous) showed slightly more erratic results. The most striking finding was that students in the same proficiency group had a tendency to behave differently when translating a $\mathrm{C}$-text (that was lexically more varied and syntactically more complex than what they had written themselves) to when translating a S-text (that was lexically less varied and syntactically simpler than their own composition). It was also striking that individual students in the same proficiency group, contrary to what one would expect, produced translations showing a wide variation with regard to the criteria mentioned in 2.0 above (see Appendix 1). If one compares the results of individual students on the translation and the mother tongue composition, there seems to be a possible relationship between the two ${ }^{3}$.

\subsection{THE LEXICAL VARIETY}

When translating the text showing greater lexical variety than their own, the students as a group decreased the lexical variety by as much as $33 \%$ on average (see for all averages Appendix 2), producing texts that were much less varied than the source text, although the students could be assumed to be sufficiently proficient to produce a text with the same lexical variety as the source text.

When translating the text showing less lexical variety than their own composition, the results were much more erratic, some students making the text lexically more varied than the source text called for, some keeping the same level of lexical variety and others making the text in translation lexically even poorer than it was, although the students' proficiency in all cases was more than sufficient to translate the Dutch text adequately without decreasing or increasing its lexical variety. The mean index decreased slightly (by ca. $4 \%$ ).

If we compare the translations of the C-text and S-text, which differed in lexical variety by as much as $42 \%$ in Dutch, we see that once translated they differ on average by no more than $16.5 \%$, having lost their characteristic lexical variety.

\subsection{SYNTACTICAL COMPLEXITY}

\subsubsection{The average clause length}

Here again we see that students translate the $\mathrm{C}$-text and S-text differently. The mean clause length of the C-text was on average decreased by ca. $18 \%$, while on the other hand the mean clause length of the S-text was on average, increased by ca. $18 \%$. Although the two source texts were in that aspect considerably different in Dutch $(9.66 / 6.01)$, they became on average nearly alike in translation (7.9 and 7.07), which means that the style of the individual Dutch texts was lost to a considerable extent. 


\subsubsection{The ratio of subordinate clauses to main clauses}

As a group the students increased the complexity of the C-text, i.e. they used relatively more subordinate constructions than the source text called for ; their number increased by $21 \%$.

When translating the S-text the students increased the relative number of subordinate clauses even more, by $29 \%$.

But, in this case, the C-text which had twice the subordination index of the S-text in Dutch, is on average still about twice as complex in translation, so that the texts can still be distinguished on that particular level.

\subsubsection{Connectives or "linkers"}

As a group the students augmented the number of subordinating connectives in all their translations. On average it was increased by as much as $61 \%$ in the translation of the C-text and by $22 \%$ in the translation of the S-text, although both source texts had in this case the same number of connectives (9). In other words : logical connections that were implicit in the source text were in many cases made explicit.

\subsubsection{The average $T$-unit length}

This decreased when the students translated the C-text by ca. $7.5 \%$ and increased when they translated the S-text, by as much as $29 \%$. The students had tended in translation to reduce the differences between the source texts ; the complex text in Dutch had an average $T$-unit length that was more than twice that of the simple text. Here again we see that students tend to level texts in translation, making them lose their distinctiveness.

\subsection{THE VERB/NOUN RATIO}

When analysing the compositions written by the students in Dutch, we were struck by the fact that students differed greatly in this respect, the $\mathrm{V} / \mathrm{N}$ score ranging from 0.78 (a relatively high degree of nominalization) to 1.52 (a high degree of verbalization). When translating the $\mathrm{C}$-text (which had a lower $\mathrm{V} / \mathrm{N}$ ratio than the average ratio of the students, i.e. where relatively few verbs were used), the students increased very slightly the percentage of verbs (by approx. $1 \%$ ).

When translating the S-text (which contained relatively more verbs than most of the students had used themselves when writing their composition) they decreased considerably the number of verbs, by $28 \%$. Whereas in Dutch, the C-text had had the lowest $\mathrm{V} / \mathrm{N}$ ratio of the two, in French it was the S-text that had become much more nominalized. Once again the source texts had changed considerably in translation, although - and we would like to stress this point - both source texts could have been translated into French without changing the $\mathrm{V} / \mathrm{N}$ ratio or, if the students had felt the need to, for stylistic reasons, they could have lowered or augmented the $\mathrm{V} / \mathrm{N}$ score in both texts to an equal degree.

\subsection{THE TEXT LENGTH}

In translation the number of words of the C-text was increased by ca. $7 \%$ and of the S-text by as much as $12.5 \%$. Once again C-texts and S-texts were treated differently.

\section{CONCLUSION}

When we look at our findings we see that it is impossible to characterize "translation in the classroom" in a general way. 
a) when translating C-texts (texts that are lexically more varied and syntactically more complex than what the students would write themselves on the same subject) :

- the lexical variety is very much decreased $(-33 \%)$;

- the number of connectives is increased $(+61 \%)$;

- the amount of subordination is increased $(+21 \%)$

- the mean clause length and the mean T-unit length are decreased $(-18 \%$; $-7.5 \%$ );

- the verb/noun ratio is hardly increased $(+1 \%)$;

- the text is only slightly lengthened $(+7 \%)$;

b) when translating S-texts (texts that are lexically less varied and syntactically less complex than what they would write themselves on the same subject) :

- the individual lexical variety cannot be predicted but as an average it is only very slightly decreased $(-4 \%)$;

- the number of connectives is increased $(+22 \%)$;

- the amount of subordination is increased $(+29 \%)$;

- the mean clause length and the mean $\mathrm{T}$-unit length are increased $(+18 \%$; $+29 \%$ ) ;

- the $\mathrm{V} / \mathrm{N}$ ratio is very much decreased $(-28 \%)$;

- the text is lengthened considerably $(+12.5 \%)$.

Whereas one would expect students to find the S-text "easier" to translate and therefore would expect them to keep its lexical and syntactical characteristics fairly unchanged, it is the S-text which in the classroom seems to be the one to be most extensively altered. Its syntactical structure and verb/noun ratio undergo drastic changes, whereas the C-text suffers mostly on the lexical level. In practice most teachers probably presume that what they are using are C-texts, but this is not necessarily true. To our knowledge texts for translation in the classroom are always selected with $\mathbf{L} 2$ in mind and never on the basis of what students would produce themselves - on the same subject - in their native tongue.

How do we know that these findings are only characteristic of translation in the classroom? Might they not also be valid for translations made by professionals?

If we take it for granted that a professional translator respects the source text as much as possible, trying to render its lexical, syntactical and stylistic particularities as well as he or she can (unless the translator consciously wants to change these in order to adapt the target text to a different group of addressees or to give it a different function) we would expect to find much the same figures for lexical variety, syntactic complexity and verb/noun ratio in both source texts and their translations made by professionals (independently from the peculiarities of the mother tongue writing of these translators).

To check whether this was true we took 12 Dutch text fragments with an argumentative subject of approximately the same lengths as the Dutch C-text and S-text and compared them with their translation into French. These translations were made by six different professional translators, under the direction of Professor Pierre Brachin of the Sorbonne, and figured in the Anthologie de la prose néerlandaise (Pays-Bas I, Historiens et essayistes). We made the same calculations as we did for the students. Our expectations were entirely fulfilled : on the whole there was hardly any discrepancy between the Dutch texts and the French texts with regard to their lexical variety, syntactical complexity and verb/noun ratio.

In conclusion, on the basis of this small-scale research it seems probable that translation in the classroom is to be distinguished from other types of translation in that it is directly related to the way the individual students express themselves in writing in 
their mother tongue, even though the group as a whole has the same degree of proficiency in the foreign language. More work will have to be done on the statistical level before we can be sure of this. We hope, though, that some of the ideas which have arisen from this small-scale survey may be of interest to others ${ }^{4}$ in the field.

Notes

1. "Die Studenten übersetzen einen Text, den sie nicht verstehen für einen Adressaten, den sie nicht kennen. Und das Produkt ihrer Bemühungen wird nicht selten von einem Dozenten beurteilt, der weder praktische Erfahrungen als Uebersetzer noch theoretische Kenntnisse in der Uebersetzungswissenschaft besitzt" (p. 28).

2. Several colleagues from other departments confirmed them in the course of private conversations.

3. This relationship was the subject of our AILA presentation, Sydney, 1987. It is also the subject of a forthcoming publication.

4. We particularly wish to thank Mrs. L. Savage, whose comments were extremely helpful.

\section{REFERENCES}

BAUSCH, K.R. and F.R. WELLER (eds.) (1981) : Übersetzen und Fremdsprachenunterricht, Frankfurt am Main.

BRACHIN, P. (éd.) (1970) : Anthologie de la prose néerlandaise, Pays-Bas I, Historiens et essayistes, Paris/ Bruxelles, Aubier/Asedi.

HÖNIG, H.G. and P. KUSSMAUL (1982) : Strategie der Übersetzung, Tübingen.

HUNT, K.W. (1967) : Sentence Structures Used by Superior Students in Grades Four and Twelve, and by Superior Adults, ERIC microfiche ED 010047.

FIUNT, K.W. (1970) : Syntactic Maturity in Schoolchildren and Adults, monograph of the Society for Research in Child Development, $\mathrm{n}^{\circ} 134$, Chicago.

KRASHEN, S. (1981) : Second Language Acquisition and Second Language Learning, Oxford.

KRINGS, H.P. (1986) : Was in den Köpfen von Übersetzern vorgeht, Tübingen.

LARSEN-FREEMAN, D. and V. STORM (1977) : "The Construction of a Second Language Acquisition Index of Development", in Language Learning, vol. 27, $\mathrm{n}^{\circ} 1$, pp. 123-134.

LARSEN-FREEMAN, D. (1978) : "AESL Index of Development", TESOL Quarterly, 12:4.

LARSEN-FREEMAN, D. (1980) : Discourse Analysis in Second Language Research, Rowley, Mass.

LIM HO-PENG (1983) : "Using T-Unit Measures to Assess Writing Proficiency", in RELC Journal, vol. 14, $n^{\circ} 1$, pp. $35-43$.

McKAY, C.L. (1983) : Writing Strategies in Spanish or French at the Secondary Level, Ph.D. dissertation, Ohio.

MELLON, J. (1981) : Sentence Combining Skills : Results of the Sentence Combining Exercises in the 1976-1979 National Writing Assessment, Denver.

MONROE, J.H. (1975) : "Measuring and Enhancing Syntactic Fluency in French", in French Review, vol. 48, $\mathrm{n}^{\circ} 6$, pp. 1023-1031.

PERKINS, K. (1980) : "Using Objective Methods of Attained Proficiency to Discriminate among Holistic Evaluations", in TESOL Quarterly, vol. 14, $\mathrm{n}^{\circ} 1$, pp. 61-69.

PFAFF, C. (ed.) (1987) : First and Second Language Acquisition Processes, Cambridge.

TITFORD, Ch. and A.E. HIEKE (eds.) (1985) : Translation in Foreign Language Teaching and Testing, Tübingen.

WESDORP, H. (1974) : Het meten van de produktief-schriftelijke taalvaardigheid, Holland, Purmerend.

WESDORP, H. (1981) : Evaluatietechnieken voor het moedertaalonderwiis, The Hague.

WIJK, C., G. van en KEMPEN (1982) : "Syntactische formuleervaardigheid en het schrijven van opstellen", in Pedagogische Studieën, 59. 


\section{APPENDIX I}

\begin{tabular}{llc}
\hline Dutch & Transi. C- & Transl. S. \\
comp. & text (0.45) & text (0.26) \\
\hline
\end{tabular}

\section{LEXICAL VARIETY}

\begin{tabular}{llll} 
1. Marcel & 0.44 & 0.33 & 0.22 \\
2. Wilfrid & 0.44 & 0.31 & 0.28 \\
3. Karin & 0.44 & 0.31 & 0.27 \\
4. Corinne & 0.43 & 0.31 & 0.21 \\
5. Jeroen & 0.41 & 0.30 & 0.26 \\
6. Liesbeth & 0.39 & 0.28 & 0.26 \\
7. Dorine & 0.39 & 0.27 & 0.28 \\
8. Simone & 0.38 & 0.30 & {$[0.25]$} \\
\hline
\end{tabular}

\section{SYNTACTICAL COMPLEXITY}

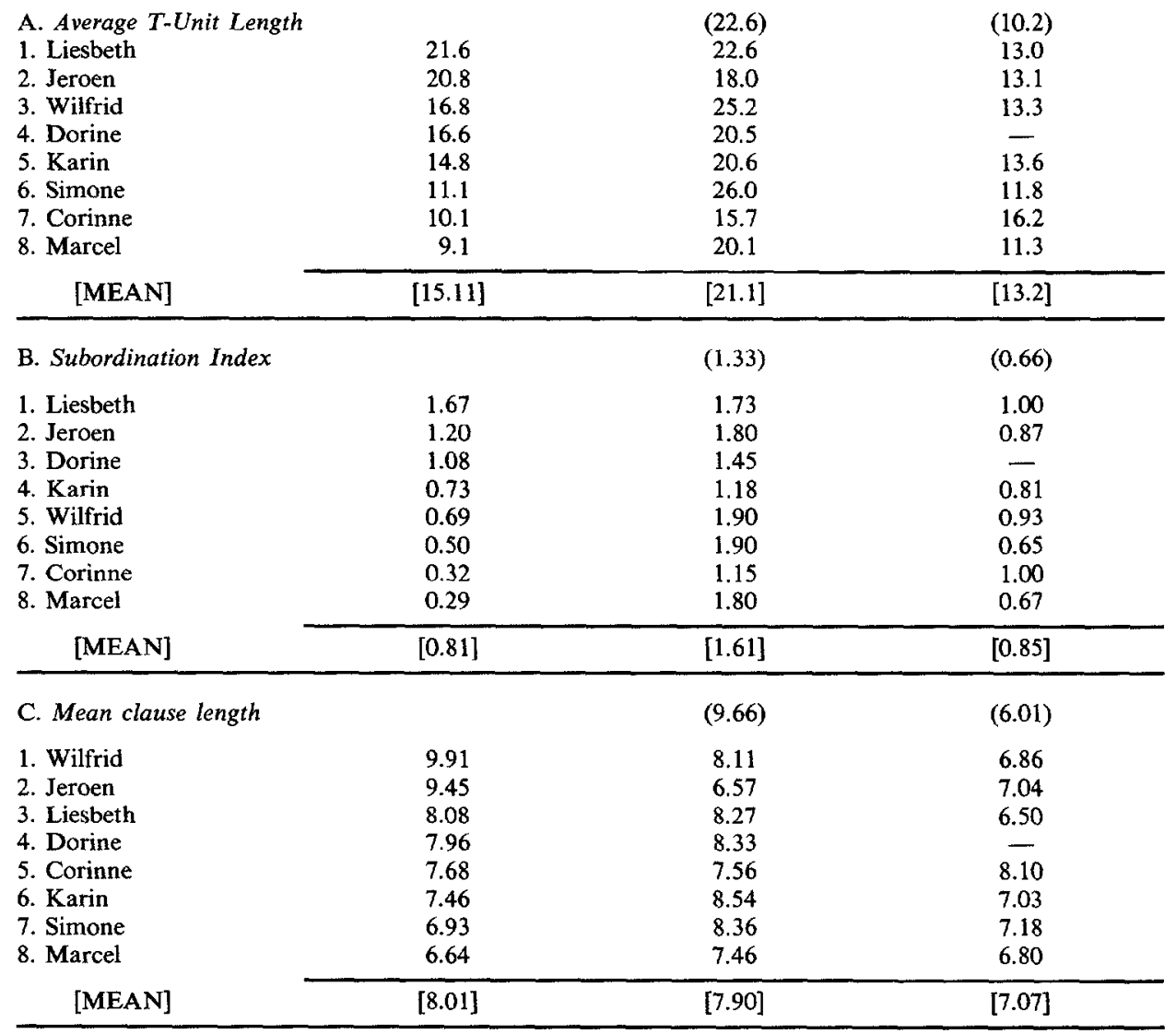




\section{VERB / NOUN RATIO}

\begin{tabular}{lccc} 
1. Wilfrid & & $(0.92)$ & $(1.05)$ \\
2. Jeroen & 0.78 & 1.11 & 0.83 \\
3. Corinne & 0.82 & 0.88 & 0.64 \\
4. Liesbeth & 0.82 & 1.09 & 0.75 \\
5. Karin & 0.88 & 0.98 & 0.82 \\
6. Dorine & 0.88 & 1.02 & 0.70 \\
7. Marcel & 0.95 & 0.93 & - \\
8. Simone & 1.14 & 0.93 & 0.88 \\
\multicolumn{1}{c}{ [MEAN] } & 1.52 & 1.00 & 0.70 \\
\hline
\end{tabular}

APPENDIX II

\begin{tabular}{|c|c|c|c|c|c|}
\hline & \multicolumn{2}{|c|}{ [Means] } & \multirow[b]{2}{*}{$\begin{array}{l}\text { Transl. } \\
\text { C-text }\end{array}$} & \multirow[b]{2}{*}{ S-text } & \multirow[b]{2}{*}{$\begin{array}{l}\text { Transl. } \\
\text { S-text }\end{array}$} \\
\hline & $\begin{array}{c}\text { Dutch } \\
\text { composition }\end{array}$ & C-text & & & \\
\hline 1. Lexical variety & 0.42 & 0.45 & 0.30 & 0.26 & 0.25 \\
\hline $\begin{array}{l}\text { 2. Syntactical Complexity } \\
\text { a) mean clause length } \\
\text { b) subordination index } \\
\text { number of s. connectives } \\
\text { c) average } T \text {-unit length }\end{array}$ & $\begin{array}{r}8.01 \\
0.81 \\
8.10 \\
15.11\end{array}$ & $\begin{array}{r}9.66 \\
1.33 \\
9.00 \\
22.60\end{array}$ & $\begin{array}{r}7.90 \\
1.61 \\
14.50 \\
21.10\end{array}$ & $\begin{array}{r}6.01 \\
0.66 \\
9.00 \\
10.20\end{array}$ & $\begin{array}{r}7.07 \\
0.85 \\
11.00 \\
13.20\end{array}$ \\
\hline 3. $\mathrm{V} / \mathrm{N}$ ratio & 0.97 & 0.92 & 0.98 & 1.05 & 0.76 \\
\hline $\begin{array}{l}\text { 4. 'Text length } \\
\text { (in number of words) }\end{array}$ & 217 & 203 & 217 & 183 & 206 \\
\hline
\end{tabular}

